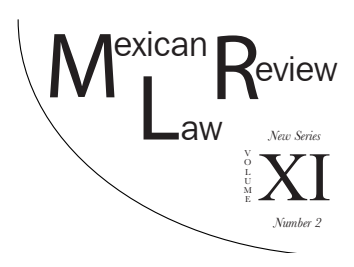

\title{
UNDERSTANDING THE RISE OF MEXICAN MIGRATION TO CANADA
}

\author{
Abdou Chekaraou Ibrahim* \\ Jisong JIAN**
}

\begin{abstract}
This article shows that the number of people seeking asylum in Canada from Mexico continues and has increased at an exponential rate. Canada has become a favorite destination for Mexican asylum seekers while Canada accepts their claims at an alarmingly low rate compared to those from other nations. We argue that the reason Mexicans choose Canada to claim refugee status is due to Canada's long history of open immigration policies and especially its economic and temporary labor agreements. These policies give the impression to Mexicans that they are welcome in Canada. This proved to be untrue when Canada changed its immigration and refugee policies in response, specifically, to the overwhelming number of Mexican refugee claims.
\end{abstract}

Keywords: Human Rights, Refugee Claimants, Mexico, Canadian Government, Temporary Foreign Worker Program, NAFTA, Immigration and Refugee Board of Canada

RESUMEN: Este documento muestra que la cantidad de personas buscando asilo en Canadá desde México continúa y ha aumentado a un ritmo exponencial. Se encuentra que Canadá se ha convertido en el destino favorito de los refugiados mexicanos, mientras dicho país acepta sus solicitudes a una tasa alarmantemente baja en comparación con las solicitudes de otras naciones. Argumento que la razón por la cual los mexicanos eligieron Canadá para pedir el estatus de refugiado, es derivado de una larga historia de política de inmigración abierta y especialmente por sus acuerdos laborales y económicos. Estas políticas dan la impresión a los mexicanos que son bienvenidos en Canadá. Sin embargo se demuestra que esto no es cierto toda vez que Canadá cambió sus políticas de inmigración y de refugiados en respuesta, específicamente, a la abrumadora cantidad de solicitudes de refugiados mexicanos.

* Doctorate Candidate (International Law, Faculty of Law, Zhongnan University of Economics and Law, China); contact at Email: abrahamzhaona@yahoo.com.

** Vice dean of the Law School, Zhongnan University of Economics and Law, China; Contact at Email:jianjisong67@znufe.edu.cn. 
Esta revista forma parte del acervo de la Biblioteca Jurídica Virtual del Instituto de Investigaciones Jurídicas de la UNAM http://www.juridicas.unam.mx/ https://biblio.juridicas.unam.mx/bjv https://revistas.juridicas.unam.mx/ http://dx.doi.org/10.22201/iij.24485306e.2019.1.13128

Palabras clave: Derechos Humanos, Refugiados, Solicitante, México, Gobierno de Canadá, Programa de Trabajadores Extranjeros Temporales, TLCAN, Consejo de Inmigración y Refugiados de Canadá

TABLE OF CONTENTS

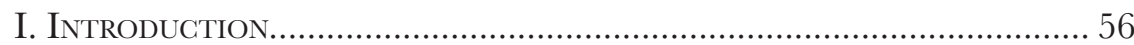

II. The History of Mexican Immigration in Canada............................. 57

1. Canadian Worker Programs ........................................................ 59

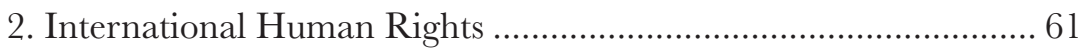

3. The Impact of NAFTA on Mexican Immigration and Asylum.... 64

III. The Mexican Refugee Glaims in Ganada ............................................ 68

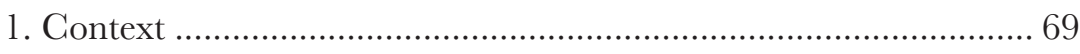

2. The Increasing Category of Mexican Refugee

Claimants: Fatalism? …………………..................................... 75

IV. Canada Policy Reforms, the Implementatiom of the IRPA and its Consequences on Mexican Refugee Claimants.................. 77

1. Reform Deterring Mexican Refugee Claimants ............................ 77

2. Designated Countries of Origin and its Real Impacts................... 79

V. Human Rights Consequences of Canada's Refugee Policy

on Mexican Refugee Claimants and Canada's International

Obligation Toward Refugee Protegtion.

1. Consequences of Canada's Asylum Policy on the Human Rights

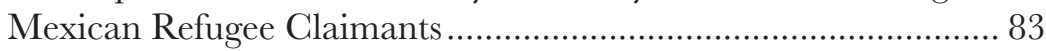

2. Canada's International Obligation Toward Refugee Protection ... 86

VI. Gonclusion. 88

\section{INTRODUCTION}

In recent years, migration from Mexico to Canada has increased at an exponential rate. The most significant and notable surge has been in the number of refugee claims from Mexicans seeking asylum in Canada. Currently, there has been little research on the subject of Mexican refugees in Canada, despite thousands of claimants each year. The mere fact that 83.2 percent of all Mexican refugee claimants were denied in 2011 alone demonstrates a disparity between the standards and requirements for obtaining refugee status in Canada and the claims by Mexicans. This causes concern and questions about the reasoning behind the lack of approval of claims from Mexicans specifically. The stories behind how Canada proceeded to change its visa policy in 2009 in response to the overwhelming number of refugee claims from 
Mexico are essential to understanding how and why Canada further revised its immigration policy in 2012, making it a quicker process from the moment a refugee claim is made to the moment the government can deport those who failed to meet the requirements of their claims. ${ }^{1}$

The Temporary Foreign Worker Program² (TFWP) in Canada allows Mexicans to work temporarily (mostly during agricultural seasons), but due to a large Mexican refugee claimant numbers, ${ }^{3}$ the Canadian Government changed its policies. In response to the backlogged system and continuous applications from Mexicans, Canada changed its immigration policies in 2009, 2010 , and then again in 2012, in an attempt to reduce the number of refugee applications, mainly from Mexico, and to expedite the process to get those denied refugee status out of the country quicker.

The TFWP, North American Free Trade Agreement ${ }^{4}$ (NAFTA), and the general relaxed immigration laws made Canada seem like a natural location for Mexicans fleeing from violence and drug wars in Mexico. Using statistical data from the Government of Canada, we will demonstrate how the changes in Canadian immigration policy have drastically and negatively affected Mexican refugees seeking asylum.

This article argues that the number of people seeking asylum in Canada from Mexico has increased at an exponential rate despite the changes made to Canadian Immigration Policies. Our work will take an interdisciplinary approach to study Mexican refugees in Canada, drawing upon the work of the media, data, and scholars to present a comprehensive look at the evolution of this phenomenon.

\section{The History of Mexican Immigration in Canada}

Mexicans did not begin arriving in Canada in significant numbers until the mid-1970s when the Canadian government expanded their TFWP to specifically recruit Mexicans to fill the unskilled labor shortage in its agriculture industry. ${ }^{5}$ As Mexicans started arriving to work seasonally for typically

\footnotetext{
1 Government of Canada, Canada Imposes a Visa on Mexico, July 13, 2009, available at https:// wrow.canada.ca/en/news/archive/2009/07/canada-imposes-visa-mexico.html (last visited July 28, 2018).

2 A program of the Government of Canada to allow employers in Canada to hire foreign nationals. Created in 1966, it originally recruited workers from Commonwealth Caribbean countries until it was expanded to include Mexicans in 1974.

$3 \quad I d$.

4 The North American Free Trade Agreement (NAFTA), Tratado de Libre Comercio de América del Norte, (TLCAN) in Spanish or Accord de libre-échange nord-américain, (ALÉNA) in French is an agreement signed by Canada, Mexico, and the United States. The agreement created a trilateral trade bloc in North America and came into force on January 1, 1994.

5 Tanya Basok, Mexican Seasonal Migration to Canada and Development: A Community-based Comparison, 41 INT'L. Migr. 2 (2003).
} 
six months at a time, this migration continued because knowledge spread about how to enter Canada and adjust to life there. The expansion of the guest worker program is why Mexicans have continued to choose Canada as a preferred destination of choice when they fear for their lives.

The importance of the history of Mexicans in Canada and their immigration patterns points to a trend which will most likely continue in the foreseeable future. Although immigration from Mexico to Canada is a recent phenomenon and occurs in much smaller numbers than it does to the United States, it still represents an important trend in migration in North America. While the TFWP has been fairly well documented and researched by scholars, general immigration information and especially the emergence of large numbers of Mexican refugee claims in Canada and its meaning has yet to be analyzed by scholars. ${ }^{6}$ This history of Mexican immigration in Canada has shaped and influenced current immigration patterns of Mexicans in Canada.

According to authors like Irene Bloemraad, the United States is more important in numbers when it comes to Latin American immigration than Canada, specifically from Mexico. The United States seems more willing and able to accept persons from Mexico into their society based on the total number of Mexican immigrants, but the percentage of persons who actually obtain citizenship and claim refugee status is much higher for Mexicans in Canada. Using census data from 1991 to 2001, Bloemraad illustrates how the United States consistently receives the most Mexican immigrants, while Canada has mostly relied on European immigration. ${ }^{7}$ However, this trend has been changing. When historically considering the policies toward immigrants and refugees in each nation, it becomes obvious why a higher percentage of Mexican immigrants in Canada become citizens and choose to claim asylum there as well.

Canada categorizes its population into permanent and temporary residents. It defines permanent residents as those individuals who have been granted permanent resident status and have not subsequently lost it; permanent residents are given all the rights of Canadian citizens with the exception of the right to vote in elections. The Department of Immigration, Refugees and Citizenship Canada defines temporary residents as persons who are legally authorized to be in Canada on a temporary basis and have the corresponding permit (i.e., a work permit, study permit, temporary resident permit, or a visitor visa). Temporary residents include foreign students, foreign workers, and visitors.

\footnotetext{
6 Richard E. Mueller, Mexican Immigrants and Temporary Residents in Canada: Current Knowledge and Future Research, 3 Migr. InT'L (Migraciones Internacionales) 1 (2005).

7 Irene Bloemraad, Becoming a Citizen: Incorporating Immigrants and Refugees in the United States and Canada, (eds), (Berkeley: University of California Press, 2006).
} 


\section{Canadian Worker Programs}

Mexicans began migrating to Canada in exponentially larger numbers when the Canadian guest worker program was expanded to fill the need for more migrant labor in the country. Canada launched a Seasonal Agricultural Worker Program (SAWP) in 1966. This was a means to address the labor shortages growers were facing in all provinces. Commonly known throughout the region as the "offshore program," it initially only applied to workers from Caribbean countries. The use of only Caribbean workers did not completely fill the labor market shortage, so it was expanded to recruit workers from Mexico in $1974 .^{8}$

Tanya Basok and other authors argue that the reason temporary immigrant labor was needed at that time and continues is because Canada needed persons willing to participate in "unfree" or captive labor. This type of labor means persons are by contract unable to change jobs once hired for their contract and must also be able to fill the request for labor whenever the need arises. ${ }^{9}$ Canadian agricultural employers prefer this type of unfree labor in order to maintain control over and stability in their working environment. ${ }^{10}$ In addition, contract workers cannot unionize or organize to improve their working conditions, except in British Colombia. ${ }^{11}$ Temporary workers are willing to comply with these conditions because they need the work and fear losing future opportunities with the program. Canadian citizen and permanent residents are unwilling to accept this type of labor because they must remain under contract, accept lower wages, and at times work under extremely strenuous working conditions. These people choose to take higher skill-level jobs that allow them freedom of movement throughout Canada, instead of being tied to the growing season or a contract.

On the other hand, the economic situation in Mexico makes Mexicans the perfect population to fill the labor void in Canada. As many rural Mexican residents lost their farmland after 1994 when Mexico opened their economy to large, foreign companies, and that land was redistributed to large land owners for mass production, these small farmers were left unemployed and had to find work to provide for their families. Canadian agricultural work was the best solution to their problems. Mexicans were willing to accept the work and conditions that went along with it. According to Basok:

8 Tanya Basok, Human Rights and Citizenship: The Case of Mexican Migrants in Canada, 72 THE Center for Comparative Immigration Studies (2003).

9 Tanya Basok, Tortillas and Tomatoes: Transmigrant Mexican Harvesters in Canada, McaILlQueen's University Press 14 (2002).

$10 \quad I d$. at 16.

11 Id. at 60-61. 
Unlike local workers, Mexicans are willing to accept minimum wages for work that is back-breaking, monotonous, and detrimental to their health. Even though Mexican labour is relatively costly because of the high transportation and accommodation costs, for many growers it is extremely valuable because it is unfree. Most Mexican workers stay with the same employer as long as there is work for them to do; they are available to work long hours every day; and they do not take time off work, even when they are sick or injured. ${ }^{12}$

Growers who use seasonal laborers through the SAWP can request workers who have worked for them in the past for the next season to ensure receiving reliable and trusted laborers. Many workers establish a relationship with a specific farmer and return year after year to the same farm. Employers are required to provide adequate housing on or near the farm for free and the laborers are required to stay there. ${ }^{13}$ Free housing is both an advantage and disadvantage for the migrant workers. They work late hours and live far from non-Mexican communities, giving them limited time in the community to interact and establish any kind of connection. However, this living arrangement gives the laborers a better opportunity to save money for their families than immigrant workers in the United States.

Mexican contract laborers are given benefits they would not receive in the United States for the same work. On average, they are paid five cents above Canada's minimum hourly wage, receive money for their transportation costs and are provided housing for the duration of their employment. Employers must arrange and pay for transportation to Canada and back to the worker's country of origin, but some of the costs can be taken out of their payroll during the season. ${ }^{14}$ This is a huge added benefit to working in Canada and helps ensure the loyalty of highly productive Mexican workers who are willing to accept their working environment and stay for the entire season. In addition, since they work long hours and are isolated from the cities, they are even available for work on weekends. ${ }^{15}$ While the migrants are entitled to a day of rest for every six consecutive days of work, they usually prefer to work as many days and hours as their employer will allow. ${ }^{16}$ Mexicans' willingness to work and accept all the terms makes them the ideal population to fill labor shortages of Canadian farmers.

More people from Mexico involved in temporary work in Canada means more people returning to Mexico after their work permits expire who will

\footnotetext{
12 Id.at 107.

13 Employment and Social Development Canada, AGREEMENT FOR THE EMPLOMMENT IN CANAdA OF SEASONAL AGRICULTURAL WORKERS FROM MEXICO - 2017, available at https://wrere.canada. ca/content/dam/canada/employment-social-development/migration/documents/assets/portfolio/docs/en/ foreign_workers/hire/seasonal_agricultural/documents/sawpmc2017.pdf(last visited July 26, 2018).

14 Id.

15 Basok, Tortillas and Tomatoes: Transmigrant Mexican Harvesters in Canada, supra note 9 at 127.

16 Id. at 119-120.
} 
tell their friends and relatives about the programs Canada offers. Mexicans learn about the benefits of choosing Canada over other destinations like the United States via word of mouth. Mexicans seeking a better life come to believe that Canada would be the best choice in situations where asylum is needed. Canada is seen as an immigrant-friendly country that offers assistance to temporary workers, as well as to asylum seekers. As success stories in Canada make their way back to Mexico, it increases the likelihood that more Mexicans wanting to find work or needing asylum will opt for Canada.

\section{International Human Rights}

Canada also has a relatively good record of upholding international human rights when it comes to immigrants. Universal human rights principles, such as those established by the United Nations after World War II, cannot be implemented and enforced without the consent of nations. Migrants are protected internationally by the United Nations International Convention on the Protection of the Rights of All Migrant Workers and Members of their Families. ${ }^{17}$ While this convention provides protection measure to migrant workers, it carries no weight if Canada chooses not to implement and enforce international human rights standards for migrant workers. In other words, if Canada were a signatory of the Convention which it is not, it would be held accountable by the international community to uphold its provisions. All migrant workers in Canada are protected under the same laws that protect all Canadian citizens. ${ }^{18}$ Even though Canada has a legal framework that protects migrant workers, they may still suffer from human rights violations, but to a much lesser degree than in other nations. ${ }^{19}$

Guest workers lack inclusion in social communities in Canada because they are usually isolated, which prevents laborers from having access to their full rights. Hence, they experience human rights violations, such as poor housing conditions, unsafe working conditions, and fear of losing their job due to health concerns. Living away from a community and in a rural area, they are physically separated from places the provide services such as medical facilities or offices where they can claim their benefits. Another reason

17 The International Convention on the Protection of the Rights of All Migrant Workers and Members of Their Families is a United Nations multilateral treaty governing the protection of migrant workers and families. Signed on 18 December 1990, it entered into force on 1 July 2003, after the threshold of 20 ratifying States was reached in March 2003. The Committee on Migrant Workers (CMW) monitors the implementation of this convention, and is one of the seven UN-linked human rights treaty bodies.

18 Tanya Basok \& Emily Carasco, Advancing the Rights of Non-Citizens in Canada: A Human Rights Approach to Migrant Rights 32 HUM.RTS. Q. 2 (2010).

19 Tanya Basok, Human Rights and Citizenship: The Case of Mexican Migrants in Canada 8 CrTIZENSHIP STUDIES 1 (2004). 
they tend to be victims of human rights violations is their acceptance to work under any and all conditions even when ill or injured because many fear they will lose their job in the future if they take off time to tend to their needs. If they speak up for their rights, they fear the consequence of being deported or not hired again the next season. ${ }^{20}$ Migrants thus suffer human rights violations when they are cut off from access to economic and social services when those services are needed.

Canada is not a signatory of the United Nations' International Convention on the Protection of the Rights of All Migrant Workers and Members of Their Families. Even though it has not signed the Convention, which would show its commitment before the international community to protect migrant workers in Canada, the country has implemented laws that do protect migrant workers including:

- $\quad$ Right to minimum wage (called prevailing wages in Canada);

- Worker compensation;

- Access to Medicare;

- Provisions of the Employment Standards Act such as vacation pay and public holiday pay if employed for at least 13 weeks (these are only granted to "harvest" and not "farm" workers).

Workers are granted one day of rest for every six consecutive days of work via the "Agreement for Employment in Canada of Seasonal Workers from Mexico." ${ }^{21}$ In addition to the aforementioned rights, migrant workers in Canada also qualify for the Ontario Health Insurance Plan (OHIP). However, their fear of losing their job prevents migrant workers from taking full advantage of their healthcare benefits when needed, showing that while Canada provides added benefits for temporary workers, they are not used to their fullest. As with all laborers who choose to migrate to a country with a language other than their primary language, this makes it difficult to communicate or understand what rights they have in that nation. This results in Mexicans' social exclusion if they cannot speak English to communicate with others in the community. In addition to not being able to understand what rights they have, the language barrier makes it more difficult for them to fully understand the procedures they need to carry out in order to take advantage of those rights granted to them. ${ }^{22}$ Employers have access to posters informing workers of their rights, but they are only required to post them in English. ${ }^{23}$

20 Basok \& Carasco, Advancing the Rights of Non-Citizens in Canada: A Human Rights Approach to Migrant Rights, supra note 18.

21 Id. at 11.

22 Id. at 13.

23 Delphine Nakache \& Paula J. Kinoshita, The Canadian Temporary Foreign Worker Program: Do Short-Term Economic Needs Prevail over Human Rights Concerns? IRPP STUdy 5 (2010). 
Despite the disadvantages they face, according to statistics, Mexicans are still choosing Canada as a location for temporary work and this trend does not show signs of slowing anytime soon. As long as they cannot find suitable work in Mexico and the demand for temporary labor in Canada remains constant, Mexicans will continue to migrate there. So far, Canada's policies have changed in many ways since Mexico's inclusion in the Seasonal Agricultural Workers Program ${ }^{24}$ (SAWP) in 1974. Among the significant changes in policy is the signing and implementation of NAFTA in 1994. Since 1867, for the most part, Canada has been liberal and supportive of those wishing to immigrate to their country. As opposed to the bureaucratic nature of the United States immigration system, Canada's system tends to cater to the needs of immigrants, including refugees, and is in favor of supporting their move toward citizenship. According to Bloemraad:

First, Canadian bureaucracy overseeing immigration and citizenship supports integration and has a normative bias in favor of citizenship. Second, federal, provincial, and municipal governments in Canada tend to offer more public assistance with the practical business of settlement and integration, subsidizing, for example, classes to learn English or programs to find a job.

To conclude this section, I argue that while immigration from Mexico to Canada is a relatively recent phenomenon, it grew to much larger numbers in the mid-1990s in areas other than temporary labor. The trend towards an increase in all types of Mexican immigration is important to study so as to understand why Mexicans, and especially refugees, are choosing Canada as a key destination. By examining the migration patterns of Mexicans to Canada, this paper can promote an understanding of the reasons for Canada's change in immigration and refugee policies in 2009, 2010, and again in 2012. In the next section I will discuss how NAFTA influenced Mexican immigration to Canada and demonstrate that NAFTA provisions caused an increase in immigration to Canada from Mexico, which contributed to Canada's implementation of a closed immigration policy in recent years.

24 The Seasonal Agricultural Worker Program is a Government of Canada program that was introduced by the Pearson government in 1966 between Canada and Jamaica but has since expanded to include Mexico and numerous other Caribbean countries. It is intended to allow Canadian farm employers to hire workers from Mexico and the Caribbean on temporary visas during the planting and harvesting seasons when employers are unable to hire local workers to fill their labor demands. The program, administered jointly by Employment and Social Development Canada with Immigration, Refugees and Citizenship Canada, is available to those who are at least 18 years of age, from one of the participating countries, qualify under the immigration laws and the country of applicant and agree to the employment contract. Those workers are eligible for the Canada Pension Plan and certain Employment Insurance benefits (excluding «special benefits» such as maternal, parental and compassionate care benefits). Workers are also subject to income tax laws. 
Esta revista forma parte del acervo de la Biblioteca Jurídica Virtual del Instituto de Investigaciones Jurídicas de la UNAM http://www.juridicas.unam.mx/ https://biblio.juridicas.unam.mx/bjv https://revistas.juridicas.unam.mx/

\section{The Impact of NAFTA on Mexican Immigration and Asylum}

The history of Mexicans in Canada has been influenced and shaped by numerous policies and practices over the years. Canada does not seem like a natural location of choice for Mexicans wishing to migrate because of its distance compared of that of the United States. This is why there was no notable increase in the number of Mexicans in Canada until the adoption of a specific policy and legislation targeted at Mexicans that offered incentives to make the trip. As explained above, significant numbers of Mexicans began arriving in Canada after the expansion of the SAWP in 1974. The SAWP became an alternative to the United States and it offered legal, social, and economic benefits that rivaled and even exceeded opportunities in the U.S. This program started the flow of Mexicans by the thousands to and from Canada each year, which aided in the relationship between the two countries. More and more Mexicans learned of the benefits of working and living in Canada from returning migrants to Mexico.

Signed in 1992, NAFTA entered into force on January 1, 1994, for the purpose of increasing economic relations between the three North American countries. The main provision of NAFTA centered on eliminating or reducing tariffs on most goods exported and imported among the three nations. The events leading up to the decision to create such an agreement were dire as thousands of people in Mexico had lost their jobs by 1993, as a result of a severe economic downturn and foreign competition. ${ }^{25}$ On other hand, Canada entered NAFTA believing it to be the best option for its economic situation. Canada used its signature as a defensive strategy to avoid losing out on the opportunity to have preferential access to Mexican markets. According to Roberto J. Mejias and José G. Vargas-Hernández:

...to have stayed out of the agreement would have allowed the United States privileged access to Mexico's tremendous market potential. From the Canadian perspective, Canada would be affected via trade diversion whether or not it joined a free trade agreement. ${ }^{26}$

Canada did not fear it would lose potential economic gains in Mexico, but rather it would lose in U.S. markets as the United States increased trade with Mexico at the expense of Canada. Canada and the United States had already entered into the U.S.-Canada Free Trade Agreement in 1989. This agreement reduced trade barriers, similar to NAFTA's provisions, which is another reason Canada was not too vested signing NAFTA. Because it essentially had already made the same deal with the United States just a few years before,

25 Jorge G. Castañeda, Can NAFTA Change Mexico? 72 Foreign Affairs 4 (1993).

26 Roberto J. Mejias \& José G. Vargas-Hernández, Emerging Mexican and Canadian Strategic Trade Alliance Under NAFTA, 14 J. of Global Marketing 4 (2001). 
Canada entered NAFTA with many reservations, as they did not have nearly as many geopolitical interests in Mexico as the United States did. In the end, Canada agreed to the tri party agreement with the mindset to welcome the opportunities Mexico's markets offered. ${ }^{27}$

Many in Mexico hoped NAFTA would aid Mexico's dying economy with foreign capital investments aimed at providing the country with sustainable growth for the future. President Carlos Salinas de Gortari used NAFTA's economic and political promise to gain support for his 1994 campaign. Salinas saw the country's falling per capita growth as a chance to attract foreign capital to finance economic growth. Author Jorge G. Castañeda argues that at the same time, Salinas hoped that by further linking Mexico's economy with the United States, the foundations would be laid for more democratic processes in Mexico and boost Salinas' political power at the same time. ${ }^{28}$ Large agricultural corporations especially took advantage of the open-door policy and shut out small-scale farmers, leaving them unemployed and in extreme poverty.

The implementation of NAFTA contributed to drastic declines in several producer prices, as well as reductions in government assistance to small-scale farmers throughout the country in order to appease corporate farms. ${ }^{29} \mathrm{In}$ creased unemployment was the effect of the NAFTA policy in Mexico that relied on foreign investors in farming. While the average farm size in Mexico increased, the total number of farms decreased. As foreign manufacturing and farming increased in Mexico, so did the use of new technologies, with which small industry and farming owners could not realistically compete. The privatization of farms in Mexico had lasting effects including "deregulation, reduced government spending and support, privatization of state industries that service the farm sector, emphasis on attracting foreign investment, and the trade and corporatization of agriculture." ${ }^{30}$ NAFTA policies also affected individuals' health, the infrastructure, and social relationships in rural communities, which led to even more adverse effects on Mexico's social and economic infrastructures. ${ }^{31}$ Increased unemployment and the despair of those who lost their farms caused unrest in rural areas among those competing for any kind of job available, whether legal or illegal. As more Mexicans found themselves unemployed, the opportunity for legal employment outside of Mexico became more and more appealing.

In 1995, the peso devaluation process caused by a stagnant economy increased the economic deficit, and the lack of credibility in the exchange rate

\footnotetext{
27 Id.

28 Castañeda, Can NAFTA Change Mexico?, supra note 25.

29 Leigh Binford, Tomorrow We're All Going to the Harvest: Temporary Foreign Worker Programs and Neoliberal Political Economy (University of Texas Press, 2013).

$30 \quad$ Id. at 48.

31 Id.at 200.
} 
Esta revista forma parte del acervo de la Biblioteca Jurídica Virtual del Instituto de Investigaciones Jurídicas de la UNAM http://www.juridicas.unam.mx/ https://biblio.juridicas.unam.mx/bjv https://revistas.juridicas.unam.mx/ http://dx.doi.org/10.22201/iij.24485306e.2019.1.13128

mechanism. ${ }^{32}$ The Mexican government was running out of options other than devaluation of its currency to turn the economy around. This was detrimental to Mexico's economy and contributed to the seemingly negative effects of opening its doors through NAFTA. The devaluation, however, did not stop the growing relationship between Canada and Mexico at the time. As Mexican businesses went bankrupt and unemployment soared, economic relations between Canada and Mexico improved. Mexico's heavy reliance on foreign investment and trade after the implementation of NAFTA increased its foreign economic capital as workers in Mexico suffered from unemployment. The economic turmoil in Mexico at this time coupled with increasing trade relations between Mexico and Canada contributed to the increased migration flow from Mexico to Canada. ${ }^{33}$ The two-way trade between Canada and Mexico more than doubled after NAFTA was implemented, going from $\$ 6.5$ billion to $\$ 15.1$ billion in a ten-year period. Canada is Mexico's secondmost important export market while Mexico is Canada's fourth-most important export market. ${ }^{34}$ As these economic relations have grown between the two nations, so has the movement of people between Canada and Mexico. Canada has always been a nation to actively petition for immigration because of the belief that immigrants, overall, have a positive economic, social and political impact on their country. ${ }^{35}$

Mexican immigration to Canada grew exponentially after the implementation of NAFTA in 1994. While NAFTA opened economic doors among the three nations, it also opened the doors to people wishing to migrate. The Treaty NAFTA visa ${ }^{36}$ (TN visa) was created to give professionals the possibility to pursue employment opportunities in another signatory nation. While this might appear to be a very viable opportunity provided by NAFTA, only 101 Mexicans were in Canada on a $\mathcal{T N}$ visa in 2001. ${ }^{37}$ Rather, as Mexico's

32 Maxwell A. Cameron, Mexican Meltdown: States, Markets and Post-NAFTA Financial Turmoil, 17 THIRD WORLD. Q. 5 (1996).

33 Mejias \& Vargas-Hernández, Emerging Mexican and Canadian Strategic Trade Alliance Under NAFTA, supra note 26.

34 Rebecca Jannol, Deborah Meyers, \& Maia Jachimowicz, U.S.-Canada-Mexico Fact Sheet on Trade and Migration, Migration Policy Institute 3 (2003).

35 E.G., The United States v. Canada, Why the differing viewes on immigration? THE Economist (Austin Texas, 2011).

$36 \mathrm{TN}$ status or TN visa is a special non-immigrant status in the United States, Canada, and Mexico that offers expedited work authorization to a citizen of these countries. It bears a similarity, in some ways, to the US H-1B visa, but it has many unique features. Within the TN set of occupations, a United States, Canadian, or Mexican citizen can work in the one of the other two countries for up to three years, but does not grant the right to apply for permanent residence. The permit may be renewed indefinitely.

37 Jannol, Meyers, \& Jachimowicz. There are four categories of NAFTA workers. Business visitors are involved in international trade activities and need to go to Canada to fulfill their duties. Intra-company transferees are Mexican or American citizens who, under certain conditions, can enter Canada with a work permit issued at the point of entry. Investors and traders are those individuals who intend to invest substantially in Canadian businesses, or who are involved in 
unemployment rate increased, the need for temporary workers in Canada increased, from which most of the upsurge in Mexican migration post-NAFTA stemmed. As trade between Canada and Mexico increased after the implementation of NAFTA, new migration flows flourished. The movement of people between the nations grew as economic connections did. Unlike the United States, Canada sought to accommodate the influx of immigrants through legal channels, including adding to the number of foreign workers. Conversely, the United States forced a majority of Mexicans to migrate illegally. This difference gave Mexicans a choice between legal or illegal migration and the costs associated with each. As migration flow levels from Mexico to Canada went up, Canada showed a greater interest in taking advantage of the legal opportunities offered. The temporary worker program was designed to minimize settlement, maximize return migration and provide better wages and working conditions and it succeeded. Douglas S. Massey and Amelia E. Brown explain:

Temporary labor migration from Mexico rose by 153 percent from 1998 to 2007, going from an annual flow of around 7,000 workers to a little under 18,000 workers in ten years. Mexico is now the second largest source of temporary workers for Canada, accounting for 11 percent of all entries of foreign workers. ${ }^{38}$

The largest increase in temporary workers was under the SAWP category, ${ }^{39}$ compared to the number of high-skilled laborers or those coming for live-in caregiving, for example. Of the Mexicans coming during this time period for temporary work, 94 percent were SAWP laborers. ${ }^{40}$ The plan was for NAFTA to place Mexico in a position to "modernize" at a very fast pace, but the result was the opposite. The reorganization of the Mexican economy after NAFTA displaced thousands of workers, leaving many unemployed and in poverty. Income gap and disparity grew in the 1990s in Mexico. While Mexico was experiencing high levels of unemployment and poverty, Canada was experiencing significant demographic changes. With its baby boomer population reaching retirement age, there was a shortage in the low skilled employment sector. This put pressure on the government to expand its temporary worker programs to fill labor shortages with programs like the SAWP. ${ }^{41}$

significant trade with Canada. These individuals are required to have work permits, which are usually issued outside of Canada. Professionals are those with advanced education, who work in certain occupations and have pre-arranged employment in Canada.

38 Douglas S. Massey \& Amelia E. Brown, New Migration Stream between Mexico and Canada, 6 Int'L, Migr (Migraciones internacionales) 1 (2011).

39 Mueller, Mexican Immigrants and Temporary Residents in Canada: Current Knowledge and Future Research, supra note 6.

40 Massey \& Brown, New Migration Stream between Mexico and Canada, supra note 38.

41 Mueller, Mexican Immigrants and Temporary Residents in Canada: Current Knowledge and Future Research, supra note 6 . 
For Mexicans lacking economic opportunities in Mexico, Canada became a legal alternative labor destination to the United States. Despite Mexico's post-NAFTA difficulties, it was able to form a lasting relationship with Canada, especially economically. Each country took advantage of what the other had to offer. Canada seized the opportunity to increase its trade relations while Mexicans used Canada as an alternative destination to the United States for employment opportunities. Their relationship was used to improve their situations both individually and collectively. Canada and Mexico even used the strength of their newfound relationship to confront the U.S. together. Using both their voices, they protested the Helms-Burton bill from passing and becoming law in the U.S. in 1996. This bill would fine or restrict any business entity that chose to or was currently exchanging goods or services with Cuba. Mexico and Canada saw this as a violation of international laws because neither country has instituted economic sanctions against Cuba. Both Canadian and Mexican officials believe that this legislation was in violation of the intent and purpose of NAFTA.

Overall, NAFTA had mixed results, but in the end each country gained something from the agreement. Although Mexico's economy essentially collapsed for Mexicans as they lost their lands, became unemployed, and lost the value of their currency, their closer relationship with Canada proved extremely beneficial. Mexico and Canada were able to successfully collaborate to protect their economic interests in Cuba against the United States. ${ }^{42}$ Also, as Mexico's economy worsened and unemployment rose, Canada expanded its temporary worker programs to accommodate more Mexicans as a legal alternative to the U.S. While the reason for increased migration from Mexico to Canada cannot be directly equated to NAFTA policies, the increased economic relationship between Canada and Mexico can somewhat be attributed to their willingness to sign the agreement and increase trade relations to the highest level they had ever stood. The next section will discuss Mexican Refugee Claims in Canada.

\section{Mexican Refugee Glaims in Ganada}

Since the implementation of NAFTA in 1994, increased illegal market activity has triggered a violent and dangerous environment forcing Mexican citizens to seek refuge. Familiar with Canada through the TFWP, Mexicans overwhelmingly choose Canada as their preferred destination to claim refugee

42 The collaboration of Mexico and Canada in order to protect their interests in Cuba against the United States was successful. Together they were able to get the Helms-Burton bill suspended so they could continue their economic trade relations with Cuba without and not have any backlash from the United States for it. This shows the progression and tangible benefits NAFTA was able to provide for Canada and Mexico, who used the Agreement to the benefit of their economic interests. 
status. While it would appear that Canada is open and welcoming of Mexicans, it has accepted only a small percentage of refugee claims from Mexico out of thousands of applicants. The refusal to accept Mexicans as refugees has left thousands of Mexicans with nowhere to turn, leaving them even more vulnerable to violence and persecution by drug-traffickers, gangs, and corrupt government officials. Refugee claims are denied for three main reasons. First, corruption in Mexico does not provide Mexican refugees with government protection or the conditions to flee within the country. Yet, Canada believes Mexico is a democratic nation that can protect its citizens. Second, Canada does not want to accept refugee claims from Mexicans for fear of hurting its trade relations with Mexico in light of NAFTA. Finally, the new Canadian refugee claim system leaves Mexicans vulnerable and unable to fully explain their situation and need for asylum.

\section{Context}

Canada signed the 1951 Convention on the Status of Refugees ${ }^{43}$ in 1969, and in 1970 the Department of Manpower and Immigration incorporated the UN convention definition of a refugee into its new guidelines for refugee admissions. The 1976 Immigration Act made those guidelines law, making it binding for Canada to adhere to the international human rights standards set by the United Nations, at least in theory. Placing international human rights law into its own country's legal system gave more legitimacy to Canada and its refugee program in the eyes of the international community. Canadian refugee policy was originally based on the 1976 Immigration Act, ${ }^{44}$ which

431951 Convention Relating to the Status of Refugees, article 42: 1. At the time of signature, ratification or accession, any State may make reservations to articles of the Convention other than to articles 1, 3, 4, 16 (1), 33, 36-46 inclusive. 2. Any State making a reservation in accordance with paragraph 1 of this article may at any time withdraw the reservation by a communication to that effect addressed to the Secretary-General of the United Nations.

44 The Immigration Act. 1976, in Canada was enacted in 1978 by the Parliament of Canada. It focused on who should be allowed into Canada, not on who should be kept out. The Act came into force in 1978, along with new immigration regulations. This Act gave more power to the provinces to set up their own immigration laws and define «prohibited classes» in much broader terms. Individuals who could become a burden on social welfare or health services would now be refused entry, rather than specific categories of people, e.g, those who identified themselves as homosexual, the disabled, and so on. Further, it created four new classes of immigrants who could come to Canada: refugees, families, assisted relatives, and independent immigrants. While independent immigrants had to take part in a points system, other classes did not have to take this test as long as they passed basic criminal, security, and health checks. The Act also created alternatives to deportation for less serious criminal or medical offenses, since deportation meant the immigrant was barred from entering Canada for life. After 1978, the government could issue 12-month exclusion orders and a departure notice, if the cause for a person's removal was not serious, but in some cases it could be severe. The 1976 Immigration 
formalized refugee policy in the country. This act gave recognition to convention refugees, as defined by the United Nations Convention Relating to the Status of Refugees, as well as to humanitarian refugees, a term used in Canada for the groups of displaced or persecuted persons who do not necessarily meet the convention definition which tends to be stricter.

The 1951 Convention relating to the Status of Refugees (the 1951 Refugee Convention) is the key international legal document that defines who is a refugee, their rights and the legal obligations of signatory countries to the 1951 Refugee Convention. ${ }^{45}$ The term "refugee" shall apply to any person who:

As a result of events occurring before 1 January 1951 and owing to well-founded fear of being persecuted for reasons of race, religion, nationality, membership of a particular social group or political opinion, is outside the country of his nationality and is unable or, owing to such fear, is unwilling to avail himself of the protection of that country; or who, not having a nationality and being outside the country of his former habitual residence as a result of such events, is unable or, owing to such fear, is unwilling to return to it. ${ }^{46}$

A Convention 'refugee' is different from an 'asylum seeker' because the former has had his or her asylum claims assessed and has been found to satisfy the above definition. This assessment can be done by a country that has acceded to the 1951 Refugee Convention or by the United Nations High Commissioner for Refugees (UNHCR). There is no such thing as a 'genuine refugee'. A refugee by technical definition is simply someone who has been recognized as meeting the above Convention definition. Further, a person is a refugee within the meaning of the 1951 Convention as soon as they satisfy the above definition. This might actually occur before their refugee status is formally determined by a country or the UNHCR. Refugee status is therefore declaratory in nature - in that, a refugee does not become a refugee because they have been recognized as one but rather, recognized because they are refugees. ${ }^{47}$ However, Canada defines a Convention refugee as:

Act was replaced by the Immigration and Refugee Protection Act (IRPA) in 2002. The enforcement team with the Immigration, Refugees and Citizenship Canada was responsible for enforcing the act at border crossings with the United States as well as at checkpoints at international airports in Canada.

45 Convention relating to the Status of Refugees (adopted 28 July 1951, entered into force 22 April 1954) 189 UNTS 137 as amended by the Protocol relating to the Status of Refugees (adopted 31 January 1967, entered into force 4 October 1967) 606 UNTS 267.

46 Article $1 \mathrm{~A}(2)$ of the 1951 Refugee Convention.

47 UN High Commissioner for Refugees (UNHCR), Handbook and Guidelines on Procedures and Criteria for Determining Refugee Status under the 1951 Convention and the 1967 Protocol Relating to the Status of Refugees, December 2011, HCR/1P/4/ENG/REV. 3, available at: http://wrerrerefworld. org/docid/4f33c8d92.html (last visited July 26, 2018). 
People who are outside their home country or the country where they normally live, and who are unwilling to return because of a well-founded fear of persecution based on race, religion, political opinion, nationality, or membership in a particular social group, such as women or people of a particular sexual orientation. $^{48}$

The Immigration and Refugee Board of Canada ${ }^{49}$ (IRB) plays a fundamental role in this matter. IRB is an independent court that makes all the decisions regarding immigration and refugee matters. When asylum claims are made in Canada, the IRB determines whether the claimant is a Convention refugee or a person in need of protection. IRB defines a person in need of protection as a person who would be subject to potential torture, a risk to their life, or a risk of cruel and unusual treatment or punishment if they were to return to their home country or the country where they normally live. As a part of the process of making an initial claim at either their port of entry into Canada or at a Citizen and Immigration Canada (CIC) office in Canada, one must bring documents including a passport, a driver's license, and any other documents proving one's identity. This makes it more difficult for individuals from Mexico who do not have this type of identity documents.

Since 1976, Canada has based its program on the Immigration and Refugee Protection Act ${ }^{50}$ (IRPA), which was passed in 2002. This Act created three separate categories for permanent residents in the country including family class, economic immigrants, and refugees. The family class consists of foreign nationals who come to Canada through the sponsorship of close relatives or direct family members. People included in this category are spouses or partners, child dependents, parents, and grandparents. Economic immigrants refer to people granted permission to work and contribute to the Ca-

48 Immigration and Refugee Board of Canada, Refugee Claims (Version 2-2013), available at https://irb-cisr.gc.ca/en/refugee-claims/Pages/ClaDemGuide.aspx (last visited July 27, 2018).

49 Established in 1989, the Immigration and Refugee Board of Canada (commonly referred to as Immigration and Refugee Board or simply the IRB, is an independent administrative tribunal that is responsible for making well-rounded and fair decisions on immigration and refugee matters, efficiently and fairly, and in accordance with the law. Established by an Act of Parliament, the IRB decides on refugee applications made by individuals who land in Canada and make an asylum claim to be in need of protection.

50 The "Immigration and Refugee Protection Act", S.C. 2001, c. 27, (IRPA") is an Act of the Parliament of Canada, passed in 2001, which replaced the "Immigration Act, 1976" as the primary federal legislation regulating immigration to Canada. The IRPA came into force on June 28, 2002. Controversially, the government failed to implement a component of the legislation that would have implemented a Refugee Appeal Division as part of Canada's immigration system. IRPA creates a high-level framework detailing the goals and guidelines the Canadian government has set with regards to immigration into Canada by foreign residents. The Immigration and Refugee Protection Regulations (IRPR) contain the laws created to fit within the IRPA in order to specify how the IRPA is to be applied. Portions of IRPA are administered by the Canada Border Services Agency. 
nadian economy. The final category is refugees, which is divided into three sub-categories: government-assisted refugees, privately sponsored refugees, and refugees landed in Canada. ${ }^{51}$ Each refugee claimant is required to fill out a Basis of Claim Form (BOC Form) ${ }^{52}$ which asks the claimant to detail who they are and specifically why they are filing their claim. Each claimant is also required to include a descriptive narrative of the events that led them to claim refugee status. This is the part where specific events are key to being accepted or rejected as a refugee. If a refugee cites a general fear without giving any specifics, their applications will most likely be rejected.

The claimant must include any actions taken to seek protection from the authorities or if they attempted to seek refuge in another part of their country. If neither action was taken, the claimant must explain why. ${ }^{53}$ Each claimant is required to provide documented proof to back their claims including any medical, travel, or police documents that verify their story. If a claimant is accepted into the program, the refugee is given assistance by the Canadian government. During a refugee's first year in Canada, the Resettlement Assistance Program (RAP) provides financial support, language training, and the Interim Federal Health Program, which gives the refugee health insurance until eligible for a provincial health care plan in the area he or she ultimately settles. However, refugees who attempt to claim protection from inside Canada are not entitled to any RAP benefits. There are several reasons that Mexicans give for claiming refugee status, including domestic violence, drug war-related fear, and persecution based on sexual orientation. Drug-traffickers in Mexico threaten the lives of those who are not willing to cooperate with them. For example, the Méndez family owned a small grocery store in Morelia, Mexico, when traffickers realized their store would be a perfect front for their drug operations. The Méndezes refused to allow the drug-traffickers to use their store, so the traffickers retaliated by threatening their lives and physically assaulting them, leaving psychological scars and forcing the family to flee to Canada.

In 2008, Mexico became the number one source country of asylum seekers in Canada with 9,527 applicants that year alone. However, only 11 percent of cases were accepted by the Immigration and Refugee Board of Canada compared to 78 percent of 3,132 Colombian claims and 42 percent of 4,936 Haitian claims accepted that same year. This data reveals the percentage of Mexicans who are turned away and sent back to Mexico or try to claim asylum in another country. Those sent to Mexico are vulnerable to further persecution and the possibility of physical, mental, and emotional trauma

51 Immigration Overview, Permanent and Temporary Residents, Government of Canada (2011). Dependents of landed refugees living abroad are also included in this category of permanent residents according to IRPA.

52 This form was previously called the Personal Information Form (PIF) before Canada reformed their system in 2012.

53 Immigration and Refugee Board of Canada, refugee claims, supra note 48. 
from drug-trafficking-related violence. Before Canada changed their visa policies, it was easy for Mexicans to get to Canada to claim asylum, whether or not their claim would be accepted. Drug-traffickers control entire regions in Mexico by paying off the police and government officials. This leaves citizens caught in the middle of cartel wars over territory with nobody to turn to for protection. One of the main reasons Canada refuses refugee claims is because they are not deemed legitimate and the Mexican government is considered "democratic" and therefore able to protect its citizens. This is clearly not the case as many officials are corrupt and bought off by bribes from cartel and gang members, making it difficult for Mexican citizens to feel protected or safe in their own country. Officially, Mexico is not in the middle of a war or under territorial occupation, making it difficult for citizens to prove their fear of persecution at home and their government's inability protect them. Refugee claimants are required to demonstrate this at a determination hearing before the IRB, and this is what makes their situation far different from the Salvadorans in the 1980s. The government of Canada officially recognized human rights violations in El Salvador, ${ }^{54}$ but they do not recognize the drug trafficking conflict that has been going on in Mexico.

NAFTA has increased illegal market activity as millions of farms went bankrupt and jobs became scarce. Many Mexicans chose to either migrate north or enter the illegal economy. The process for obtaining refugee status in Canada includes an inquisitorial hearing, which requires the IRB to do an extensive background check into the conditions of the claimants' home country. The Canadian government pays for this research. By not needing a lawyer, this makes it financially easier on the claimant as the government does not use a lawyer to represent its position either. By leaving it mostly in the hands of the IRB, it can leave claimants from Mexico vulnerable to being denied refugee status because they are often not able to fully explain their situation. When the IRB investigates and fails to find any certified danger, such as war or an armed conflict in their country of origin, claimants have a harder time proving their need for asylum. ${ }^{55}$ Language barriers and the inability to fully understand legal processes and terms associated with claiming refugee status in Canada can lead to the claimants' failure to understand what is needed and to adequately explain their situation and need for asylum. I believe this is the case with Mexican claimants in Canada who are unable to effectively convey their fear of the violence they have experienced without having anywhere else to turn to for help due to corruption in Mexico.

In Canada, there are three types of hearings: expedited, regular, and extended. Most claimants go to a regular hearing to have their claims determined. If the claimant is from a high-acceptance-rate country or their case

54 María Cristina García, Seeking Refuge: Central American Migration to Mexico, The United States, and Canada (Berkeley and Los Angelos: University of California Press, 2006.

55 Rebecca Hamlin, International Law and Administrative Insulation: A Comparison of Refugee Status Determination Regimes in the United States, Canada, and Australia 37 Law \& Soc. Inourry 4 (2012). 
fits the "basic profile", they go through an expedited process to free up the system for those with a less clear-cut case. Expedited processing does not involve the board members directly; an officer meets with the claimants instead to either verify their stories and grant them refugee status or recommend them for a regular hearing. Extended hearings are for more complex cases and are presided over by a board member. ${ }^{56}$ Another method the IRB uses to make consistent judgment calls on refugee cases is identified cases that use "leads" or precedents to guide their decisions and make the process more independent from the court system.

The goal is to designate a specific case as a "lead" and use it as a precedent for all future cases from a given country. This is mostly used when claims from a specific country rapidly increase and it streamlines the process and makes judgments across board members in all areas of the country more consistent. In recent years, this approach has been somewhat applied to Mexican refugee claims in Canada. The IRB modified the process by selecting three cases as "Persuasive Decisions." These decisions occurred after the fact and do not have the broad general application language that "lead" decisions have, but they are still used as guidelines for future decisions. All three of the cases chosen as examples for Mexican refugee claims were rejections, stating that the claimants had the option of state protection in Mexico. This 2006 ruling set the precedent in many ways for future Mexican claims, by stating that they are not truly refugees. Claim rates dropped 35 percent in 2006 to stand at only 15 percent the following year and 11 percent in $2009 .{ }^{57}$ The use of the Persuasive Decisions can be seen as controversial since the cases used for the Persuasive Decisions are not generalizable for all the cases from Mexico. These Decisions discount corruption, which eliminates the inflight option of many people fleeing from violence and death threats. This eliminates the need for interaction with the court system leaving more room for flexibility in accepting refugee claims. However, the Persuasive Decisions strategy can also lump together all the claims from the same country despite the different concerns and needs. Claims plummeted and continued to drop. The cost of eliminating visas has been pegged at $\$ 261.9$ million over 10 years, after factoring in the prospect of increased tourism and travel dollars from Mexicans. The number of flights between the two countries has increased, though some immigration service providers point out that these increases have led to the corresponding increase in asylum claims - it is easier to get to Canada from Mexico. Statistics from British Columbia show that in December 2016 and January and February 2017, there were 29 refugee claimants from Mexico compared to 30 who arrived between December 2015 and November 2016. The majority of the newcomers claimed asylum at the Vancouver airport. ${ }^{58}$

\footnotetext{
Id. at 948.

57 Id. at $948-949$

58 Stephanie Levitz, Asylum claims lodged in Canada from Mexico rise again in March, CBC News,
} 
Since NAFTA entered into force, Mexican refugees in Canada have gone through a journey with which many people are unfamiliar. As NAFTA increased levels of unemployment leading to increased activity in illegal markets, the corruption and violence stemming from large-scale drug-trafficking forced thousands of Mexicans to flee and attempt to find asylum in Canada. Within only a few years, the rapid increase in claims became too overwhelming for the Canadian IRB system, so it responded with a series of immigration and refugee policy reforms that ultimately targeted Mexican refugee claimants. These policies aimed at deterring claims while streamlining the process in order to assist those with "legitimate" claims from countries whose government cannot protect them. Unfortunately, Mexico is not one of these countries.

\section{The Growing Category of Mexican Refugee Claimants: Resignation?}

The number of people seeking asylum in Canada from Mexico continues to rise. New figures from the IRB show that March reached a record high of new claims in 2017 - 110, up from 85 in February and 71 in January, making a total of 266 so far that year. Statistics from the IRB show that there were just 241 claims in 2016. Canada experienced a 700\% rise in asylum claims from Mexico compared to the number of claims made in January $2016 .{ }^{59}$ February 2017 saw a 2, 500\% increase from February of the previous year, according to a new report by the True North Initiative ${ }^{60}$ based on IRB data. In December 2016, the Canadian government lifted the visa requirement for Mexicans to travel to Canada and an increase in claims was projected. The volume of asylum seekers from Mexico had been the reason the previous government begin to require visas in 2009, but the move caused diplomatic bad blood between the two countries. ${ }^{61}$

As with those arriving at our border on foot, any foreign national in Canada can ask for asylum and apply to be a refugee. The person must demonstrate to a Canadian judge that they meet the legal definition of a refugee - that they face a well-founded fear of persecution and that their home country has failed to provide safety and protection. In the meantime, applicants are given full access to Canada's generous social safety net, including the controversial Interim Federal Health Program — which offers services above and beyond

The Canadian Press, April 16, 2017, at http://werre.cbc.ca/neres/canada/british-columbia/asylumclaims-lodged-in-canada-from-mexico-rise-again-in-march-1.4072425 (last visited July 28, 2018).

59 Charlie Gillis, Why rich Mexicans are fleeing to Canada as refugees ? MACLEAN's, Dec.11, 2012, available at http://wrere.macleans.ca/newes/canada/wealth-asylum/(last visited July 28, 2018).

60 Asylum Claims from Mexico Spike, TRue NoRTh InITIATIVE, available at http://wrerre.truenorthinitiative.com/mexicospike ( last visited July 28, 2018).

61 Stephanie Levitz, Mexican Asylum Seekers Apply To Canada In Record Numbers, THe CANadian Press, April 16, 2017, at http://wrere:huffingtonpost.ca/2017/04/16/mexico-refugeescanada_n_16052976.html (last visited July 28, 2018). 
what Canadian taxpayers receive. But Mexican asylum seekers typically fail to meet Canada's standard of a refugee. Prior to the 2009 decision to impose a visa on Mexican travellers, Canada received nearly 10,000 Mexican asylum seekers in 2008. Only about $10 \%$ of those applications were eventually accepted and granted refugee status in Canada. The remaining 90\% of cases were either abandoned by the claimant or rejected by a Canadian immigration judge. These claimants cost Canadian taxpayers hundreds of millions of dollars annually through social welfare programs, legal aid, court costs and deportation services. The low acceptance rate for Mexican asylum seekers is due to the fact that, although Mexico is a dangerous country, simply coming from a dangerous place is not enough to qualify for asylum in Canada. A person must face direct persecution, and most Mexicans are not persecuted in the way set forth by legal definitions.

In Daniel Balcorta, ${ }^{62}$ a rich, former professional Mexican soccer player, who lived in Canada as a claimant had it good. Three cars, a house with a pool, lavish meals at Cancun's top restaurants - such were the perks of a successful realtor selling beachfront property on the Yucatan coastline. Balcorta had paired minor celebrity with a strong grasp of Internet commerce, and developed a thriving business catering to well-heeled snowbirds from the U.S. and Canada. "I even had a private jet to fly my clients around to view properties," he says "We lived a very comfortable life." One call would change that. The man with the raspy voice on the other end introduced himself as a representative of "the Company" - gangster-speak for Los Zetas, a notorious criminal cartel known throughout Mexico for drug trafficking and extortion. The time had come for Balcorta to pay up, the man said, and the price was 500,000 pesos (about \$50,000). "You must have the wrong person," Balcorta responded and promptly hung up, but the man called back, and thus began a month-long nightmare during which the gangsters called Balcorta and his wife, Maria, no less than 10 times demanding they pay up or else. When the Balcortas stopped answering, the gangsters left voice mails threatening their lives and those of their children, aged 5 and 2. Maria took a call at the house in which a man told her Zetas would kill Balcorta "or a member of your family" unless she persuaded her husband to co-operate. They reported this to the police - twice - but the calls kept coming. The tipping point came few days later, when the family returned from the luxury mall at Plaza la Isla to find their gate ajar and their front door pried open. The contents of the house were untouched: "they'd left $\$ 200$ on the table to pay some bills." "They didn't take it." But by then they had noticed strangers watching their house from vehicles parked on the street. When their call to police about the breakin went unanswered yet again, the Balcortas planned their escape. That day, they moved to a friend's house, and few days later, they boarded a plane for Calgary (Canada) where they claimed asylum under Canada's refugee pro-

62 Gillis, Why rich Mexicans are fleeing to Canada as refugees?, supra note 59. 
tection laws. In the last six years, there have been some 286,000 complaints of extortion in the country while an estimated two million shakedowns go unreported each year, most of them done over throwaway cellphones. ${ }^{63}$

Another example is Javier Castillo Mendoza. Castillo, a former distributor of Hewlett-Packard office equipment, testified that he received a series of demands for cash over the phone before he was kidnapped by corrupt police officers in August 2005. He was released, he said, after his wife delivered an $\$ 8,000$ ransom to a local police station. After receiving another extortion demand in April 2007 - this time for $\$ 25,000$ - he closed his business and fled to Toronto (Canada) with his wife and four children. ${ }^{64}$ Mendoza's plight, in turn, closely resembled that of Alejandro Blando, a distributor of wireless network plans, who in 2008 came under threats from men claiming ties with Mexico's Federal Investigation Agency. In Blando's case, the callers did not want money but undocumented phone lines through which — presumablythey could conduct illegal business. ${ }^{65}$

\section{Canadian Policy Reforms, the Implementation of the IRPA and its Consequences for Mexican Refugee Claimants}

Since 2002 and the implementation of the IRPA, Canada has made three significant changes to their immigration and refugee system. As refugee claims from Mexico have increased at a high rate despite the low acceptance rate, the Canadian government reacted with policy reforms that specifically affected Mexicans, starting with visa requirements in 2009, then passing the Balanced Refugee Reform Act, and finally overhauling their asylum system in 2012. With the first change in 2009, refugee claims from Mexico dropped significantly. Canada's reforms to immigration and refugee policy achieved its ultimate aim of deterring Mexicans from claiming asylum in Canada.

\section{Reform Deterring Mexican Refugee Claimants}

Starting in 2009, Canada began a series of reforms that substantially affected Mexican immigration to Canada and especially immigrants seeking refugee status. Due to the large influx of refugee claims, most of which were rejected by the IRB, the government of Canada decided it needed to take action to protect those with legitimate asylum needs by streamlining the process and requiring that all Mexican nationals apply for a Temporary Resident Visa prior to travelling to Canada. In a press release, the Government

$\begin{array}{ll}63 & I d . \\ 64 & I d . \\ 65 & I d .\end{array}$


Esta revista forma parte del acervo de la Biblioteca Jurídica Virtual del Instituto de Investigaciones Jurídicas de la UNAM http://www.juridicas.unam.mx/ https://biblio.juridicas.unam.mx/bjv https://revistas.juridicas.unam.mx/ http://dx.doi.org/10.22201/iij.24485306e.2019.1.13128

of Canada explicitly stated the number of Mexican refugee claims was the pushing factor behind the implementation of the visa requirement. The government hoped this would be a step toward reducing the abuse of the refugee system by persons wishing to immigrate quicker to Canada. ${ }^{66}$

The second reform took place the following year, in 2010, and specifically targeted refugees. The Balanced Refugee Reform Act was introduced by the Refugee Appeals Division (RAD) in an attempt to have the bill passed in 2002. On Parliament's first try, the IRB thought it redundant to add an appeals process as the process was already quite thorough and strong. Courts take a very hands-off approach and ultimately only take less than 15 percent of cases requesting to be heard. This demonstrates the level of trust and cooperation between the courts and the IRB, making for more streamlined refugee claim processes. This is what originally fueled their belief that a RAD was not needed to successfully process all the claims. As claims became exponentially more numerous, the need for reform became apparent. The Balanced Refuge Reform Act was passed in 2010 by Parliament, adding an Appeals Division that was established in 2002. In addition to adding an appeals processing division, the Act reformed the process for low acceptance rates to make the process more expedient. The other aspects of the system remained intact as the main aim was to reduce the number of claims going to the court system. This reform also sought to reduce applications from high claim countries like Mexico. Since Mexico had low acceptance rates, Canada can more easily expedite those claims to streamline the process. This is yet another way that Canada can easily deter or quickly process and then deport Mexicans making refugee claims.

The most recent and ultimately the most extensive reform to the refugee claims system in Canada came in 2012 when Parliament passed the Protecting Canada's Immigration System Act (known as Bill C-31). Effective on December 15, 2012, this piece of legislation further reformed the system for seeking asylum, adding measures to address human trafficking, as well as requiring data collection as a part of the temporary resident visa, work permit, and study permit applications. ${ }^{67}$ While still allowing all claimants to get a fair oral hearing before the Immigration and Refugee Board of Canada, Bill C-31 streamlines the process to accelerate judgments on the cases. Those whose claims are accepted are promptly given refugee status, while those whose claims are denied will be deported more quickly as well. This Act identifies "Designated Countries of Origin"68 (DCO), which labels a country as capable of democratically protecting its citizens. Mexico is included in the

\footnotetext{
66 Citizenship and Immigration Canada, Canada Imposes a Visa on Mexico, supra note 1.

67 Canadian Council for Refugees, Overview of C-31 Refugee Determination Process, Feb. 21, 2013, available at http://ccrweb.ca/en/overview-c-31-refugee-process (last visited July 28, 2018).

68 Government of Canada, Designated countries of origin policy. On July 23, 2015, the Federal Court made a decision that affects the right to appeal to the Refugee Appeal Division of the Immigration and Refugee Board (IRB) of Canada, available at https://wrew.canada.ca/en/im-
} 
list of DCOs, meaning that individuals making refugee claims from Mexico have fewer rights during the refugee process to have their claims heard in detail. Claimants from DCOs do not have appeal privileges. This Act potentially leaves thousands of Mexican refugee claimants in a vulnerable situation. These claimants will inevitably be rapidly deported back to Mexico where the very people they are seeking protection from, most likely, still reside.

\section{Designated Countries of Origin and its Real Impact}

Canada's previous federal government circumvented its legal obligations to refugees. In December 2012, Bill C-3 1: Protecting Canada's Immigration System Act substantially changed Canada's refugee determination system. ${ }^{69}$ Bill C-31 gave the Minister of Citizenship and Immigration the power to identify certain countries considered presumptively safe as "Designated Countries of Origin" (DCOs) for the purpose of deciding asylum claims. ${ }^{70}$ Canada added Mexico to the DCO "safe" list in February 2013. ${ }^{71}$ As of April 2016, there were 42 countries on the DCO list. ${ }^{72}$ Until July 2015, refugee claimants from DCO countries were barred from access to appeal a negative refugee determination to the newly created Refugee Appeal Division (RAD) of the Immigration and Refugee Board (IRB). It was also possible to deport failed DCO claimants from Canada immediately after a negative ruling on their refugee claim; they did not have a right to an automatic suspension of deportation while pursuing a review of a negative decision at the Federal Court level. The lack of access to the RAD had far-reaching consequences: an August 2015 Osgoode Legal Studies Research Paper reported that over 25\% of failed refugees succeeded on appeal at the RAD, indicating a high number of flawed decisions at the IRB level. ${ }^{73}$

migration-refugees-citizenship/services/refugees/claim-protection-inside-canada/apply/designated-countriespolicy.html (last visited Feb. 8, 2017).

69 House Government Bill (Bill C-31), Protecting Canada's Immigration System Act, SC 2012, c 17, 41st Parliament, 1st Session June 2, 2011 - September 13, 2013, available at http://wrwre.parl. gc.ca/LegisInfo/BillDetails.aspx?'Language $=E \mathcal{E} M o d e=1$ EbillId=5383493 (last visited July 28, 2018).

70 The category of DCOs was originally introduced by the Canadian government by the Balanced Refugee Reform Act [BRRA] of 2010 as amendments to the Immigration and Refugee Protection Act [IRPA]. The original amendments, however, never came into force. Bill C-31 modified the BRRA (s. 109.1). Id.

71 Government of Canada, Designated countries of origin policy, supra note 68.

72 Id. (The countries are: Andorra; Australia; Austria; Belgium; Chile; Croatia; Cyprus; Czech Republic; Denmark; Estonia; Finland; France; Germany; Greece; Hungary; Iceland; Ireland; Israel (excluding Gaza and the West Bank); Italy; Japan; Latvia; Liechtenstein; Lithuania; Luxembourg; Malta; Mexico; Monaco; Netherlands; New Zealand; Norway; Poland; Portugal; Romania; San Marino; Slovak Republic; Slovenia; South Korea; Spain; Switzerland; the United Kingdom; the United States of America).

73 Sean Rehaag \& Angus Gavin Grant, Unappealing: An Assessment of the Limits on Appeal 
Esta revista forma parte del acervo de la Biblioteca Jurídica Virtual del Instituto de Investigaciones Jurídicas de la UNAM http://www.juridicas.unam.mx/ https://biblio.juridicas.unam.mx/bjv https://revistas.juridicas.unam.mx/ http://dx.doi.org/10.22201/iij.24485306e.2019.1.13128

In Y.Z., the Honorable Justice Boswell found that the RAD bar for claimants from DCO countries contravenes Section 15 of the Canadian Charter of Rights and Freedoms (the right to equality and non-discrimination). ${ }^{74}$ The decision results in claimants from DCO countries not being able to file an appeal with the RAD, which includes a suspension of deportation from Canada while seeking this appeal. ${ }^{75}$ While the government launched an appeal of Justice Boswell's judgment to the Federal Court of Appeal after the 2015 fall election, the new Liberal government withdrew the appeal, leaving Justice Boswell's decision, as well as its positive implications for DCO claimants, intact. DCO refugee claimants were also denied access to publicly funded healthcare under the Interim Federal Health Program (IFHP), with the exception of care required to treat a medical condition deemed a risk to public health. This "public health and public safety" coverage included antiretroviral medications and other HIV-related care. ${ }^{76}$

As of April 1, 2016, the Liberal government has reinstated full IFHP coverage for all refugees. This means that claimants from DCO countries have the same level of healthcare as all other refugee claimants. ${ }^{77}$ Finally, the Liberal government has promised to institute an "expert human rights panel" to determine DCO designations. ${ }^{78}$ As of April 2016, the specifics of the composition of this panel and the process for DCO designation (and de-designation) have not been announced. Even so, with or without input from such a panel, the government of Canada has the authority to remove Mexico from the DCO list.

In a 2012 report, the United Nations High Commissioner for Refugees (UNHCR) stated that designating a country as "safe" for the purposes of expediting asylum applications is not prima facie problem. ${ }^{79}$ However, such a designation would need to be used only in "carefully circumscribed situa-

Rights in Canada's New Refugee Determination System, Osgoode Legal Studies Research Paper SERIES 42 (2015).

74 YZv Canada (Minister of Citizenship and Immigration), 2015 FC 892, [2015] FCJ No 880 $[$ YZv Canada $]$.

75 Immigration and Refugee Protection Act, S.C. 2001, c. 27 at ss 49(1)(c), (2)(c).

76 Justice Law, Order Respecting the Interim Federal Health (SI-2012-26), available at http:/ /lawslois.justice.gc.ca/PDF/SI-2012-26.pdf; See also; Canadian Doctors for Refugee Care, The Issue, available at http:/ /www.doctorsforrefugeecare.ca/the-issue.html (last visited July 28, 2018).

77 Government of Canada, Restoring Fairness to the Interim Federal Health Program, Feb. 18, 2016, available at https://werere.canada.ca/en/immigration-refugees-citizenship/newes/2016/02/restoring-fairness-to-the-interim-federal-health-program.html (last visited July 28, 2018).

78 Justin Trudeau, ARCHIVED - Minister of Immigration, Refugees and Citizenship Mandate Letter, Nov.12, 2015, Prime Minister of CANada, available at https://pm.gc.ca/eng/archived-ministerimmigration-refugees-and-citizenship-mandate-letter (last visited July 29, 2018).

79 UNHCR, UNHCR Submission on Bill C-31: Protecting Canada's Immigration System Act (May 2012) at para 31, available at http://werre.unhcr.ca/wp-content/uploads/2014/10/RPT2012-05-08-billc31-submission-e.pdf; Prima facie is a Latin expression that literally reads as "at first face" and is used in legal terms to refer to its first appearance, subject to further informa- 
tions" and be based on "reliable, objective and up-to-date information from a range of sources," including compliance with human rights instruments and openness to human rights monitoring. ${ }^{80}$ Importantly, UNHCR highlighted that the designation of a country as a safe country of origin cannot establish an absolute guarantee of safety for the residents of that country. ${ }^{81}$ While the appointment of an expert human rights panel may reduce concerns about DCO designations being made arbitrary or without proper consideration, the DCO system remains problematic, particularly because of its impact on claimants who are living with or vulnerable to HIV infection. Although DCO claimants now have access to the RAD and healthcare through the IFHP, other obstacles to full access to justice and procedural fairness exist for claimants from designated "safe" countries.

A country that may be safe for the majority of the population may be unsafe for certain minority groups. ${ }^{82}$ The success rate of sexual orientation claims for countries that do not otherwise produce a great number of Convention Refugees is illustrative of this fact. A country that appears politically progressive -i.e., has legislated human rights protection and has ratified international instruments - may not have the protocols or resources to ensure the exercise and protection of these rights. This is particularly true for populations that have traditionally been marginalized, such as populations living with HIV and those from groups with a high risk of infection. This includes populations that, for reasons of their gender, sexuality, citizenship status, or social class, are made all the more vulnerable by their HIV status and are not adequately protected by the government. Such populations tend to be stigmatized, criminalized and discriminated against, and are often rendered invisible in statistics purportedly representative of a larger population. ${ }^{83}$

Refugee claimants with fears based on their sexual orientation or gender identity face legal obstacles that can be compounded by coming from a

tion. See Cornell University Law School, "Prima Facie", Legal Information Institute, available at https://wrwre.law.cornell.edu/wex/prima_facie (last visited July 29, 2018).

$80 \quad$ Id.at paras $31,32$.

81 Id.at para 31.

82 Id., Canadian Association of Refugee Lawyers (CARL) Presse Release: Designated Country of Origin Scheme is Arbitrary, Unfair, And Unconstitutional, December 14, 2012, available at http:// wwre.carl-acaadrca/our-work/issues/DCO (last visited July 27, 2018).

83 The quantitative criteria neglect entire subsets of claimants. A country that is safe for most claimants will have a low acceptance rate, but it may have a high recognition for subsets of the population. This is most often the case with gender and sexual orientation-based claims. Statistics have shown that these claimants tend to come from countries with overall low recognition rates, like Jamaica for example, yet when their claims are isolated it is clear that they have generally higher recognition rates than other claimants. The result is that claims from subsets of the population are subject to DCO rules, even though their claims are likely wellfounded. 12 v Canada, Affidavit of Sean Rehaag, supra note 73 at paras 31-42. 
Esta revista forma parte del acervo de la Biblioteca Jurídica Virtual del Instituto de Investigaciones Jurídicas de la UNAM http://www.juridicas.unam.mx/ https://biblio.juridicas.unam.mx/bjv https://revistas.juridicas.unam.mx/ http://dx.doi.org/10.22201/iij.24485306e.2019.1.13128

DCO country and living with or being vulnerable to HIV. ${ }^{84}$ A claimant from a DCO country has half the time to prepare for a refugee hearing after filing a Basis of Claim form - that is, 30 days as opposed to 60 days for all other claimants. ${ }^{85}$ Because of the sensitive nature of claims based on sexual orientation, sexual minority status or gender-based violence, there are many factors that contribute to challenges in presenting these claims within the shortened timeframe set out in the DCO regime. After what may be years of hiding their identity or being silent about gender-based or sexual abuse, many do not feel safe enough to share such information or acquire documentary evidence from their countries immediately upon arrival while seeking legal representation and navigating a new country. ${ }^{86}$ Many experts note that claimants may not make important disclosures to their lawyers in a first meeting; it often takes months to establish trust. ${ }^{87}$ This is particularly true for claimants who have experienced trauma or who are not comfortable disclosing sexual violence, sexual orientation or HIV status.

An additional factor is that some claimants may only discover their HIV status on taking the required Immigration Medical Exam (IME) ${ }^{88}$ Claimants must then cope with their diagnosis and disclose this status to their counsel in an extremely short timeframe, which in turn might result in their health status not being included as grounds of risk at their refugee hearing. Another impact of this designation is that failed claimants from DCOs cannot apply for a Pre-Removal Risk Assessment (PRRA) for 36 months after their refugee claim has been denied, compared with the 12-month bar on PRRAs for other claimants. $^{89}$ The PRRA presents an opportunity for failed refugee claimants to show that they face a risk in their country based on new evidence arising after their refugee claim was refused. Risk assessment is of particular importance

${ }^{84}$ For a compilation of appellate decisions reviewing rejected refugee claims based on sexual orientation and gender identity, many of the appeals profiled involved claims made by Mexican nationals, see Nicole Laviolette, Canadian Appellate Level Decisions Dealing with Refugee Claims Based on Sexual Orientation and Gender Identity - Listed According to the Definition of a Convention Refugee (2015), available at http:/ / papers. ssrn.com/sol3/papers.cfm?abstract_id=2594937 (last visited July 27, 2018).

85 Immigration and Refugee Protection Act, at s 111.1(2); See also Immigration and Refugee Board of Canada, refugee claims (Version 2 - 2013), supra note 48.

86 International Human Rights Program Interview of Adrienne Smith (by email), (15 October 2015); YZv Canada at para 60; Sean Rehaag, Patrolling the Borders of Sexual Orientation: Bisexual Refugee Claims in Canada, Mcgill L.J. 53-59 (2008); Envisioning Global LGBT Human Rights, Envisioning LGBT Refugee Rights in Canada: Is Canada a Safe Haven?, (September 2015), available at http://yfile.news.yorku.ca/files/2015/09/Is-Canada-A-Safe-Haven-Report-2015. pdf; Nicholas Hersh, Challenges to Assessing Same-Sex Relationships Under Refugee Law in Canada, McGill L.J. 60. (2015).

87 rZv Canada at paras 59, 63, 65.

88 Immigration and Citizenship Canada, Who must submit to an immigration medical examination?, http://wrerre.cic.gc.ca/english/resources/tools/medic/exam/who.asp (last visited Feb.10, 2018).

89 Immigration and Refugee Protection Act, at ss 113(a), 112(2)(b.1). 
for claimants who may not have been able to disclose their HIV status, past sexual or gender-based violence, or sexual orientation in their initial refugee claim, and fear persecution if returned to their country.

\section{Human Rights Gonsequences of Ganada's Refugee Policy on Mexican Refugee Glaimants and Canada's International Obligations toward Refugee Protection}

Canada has preserved its humanitarian tradition through the ratification of international conventions, human rights laws, and even a revision of its constitution in 1982. Due to the apparent generous nature of Canada's immigration policy towards Mexicans, many have used the opportunity during crises caused by violence and discrimination throughout Mexico. As a result of numerous claims of asylum from Mexico, Canada responded with a strict immigration reform on three different occasions, effectively eliminating any viable asylum claims from Mexico.

\section{Consequences of Canada's Asylum Policy On the Human Rights of Mexican Refugee Claimants}

For a member of the IRB, the designation of "safe" indicates the Minister's opinion about refugee claims from Mexico, which could affect a claimant's chance of success at having their claim accepted in Canada. ${ }^{90}$ As Justice Boswell stated in the case of Y.Z., the distinction between DCO and non-DCO claimants is "discriminatory on its face," serves to "marginalize, prejudice, and stereotype" DCO claimants and perpetuates a stereotype that they are "somehow queue-jumpers" or "bogus," in that they only came to Canada to take advantage of its refugee system and its generosity. ${ }^{91}$ Canada's designation of Mexico as a "safe" country was part of a massive overhaul of the refugee determination system. The rationale for the designation was that Mexico, an important trade partner, respects human rights and protects its citizens. Thus, by extension, any refugee claim against Mexico must be "bogus" and unfounded. However, this paper concludes that Mexico remains un-

\footnotetext{
90 Audrey Macklin, "A safe country to emulate? Canada and the European refugee" in The Global Reach of European Refugee Law (Cambridge: Cambridge University Press, 2013) 99 at 103.

91 $Y Z v$ Canada at para 124. Refugee claims that fail the refugee determination process, moreover, should not be understood to be fraudulent. With a highly technical and restrictive refugee definition, many individuals who genuinely fear persecution are unable to meet the Refugee Convention criteria. Labeling these individuals with derogatory terms is harmful to the entire refugee system. Canadian Council for Refugees, Concerns about changes to the refugee determination system (December 2012), http://ccrweb.ca/en/concerns-changes-refugee-determination-system (last visited July 28, 2018).
} 
Esta revista forma parte del acervo de la Biblioteca Jurídica Virtual del Instituto de Investigaciones Jurídicas de la UNAM http://www.juridicas.unam.mx/ https://biblio.juridicas.unam.mx/bjv https://revistas.juridicas.unam.mx/

safe for many Mexicans. The country should be removed from Canada's Designated Country of Origin (DCO) list. The impact of designation is potentially harmful to refugee claimants because they are afforded fewer procedural rights, and coming from a country labeled "safe" can foster prejudgment among decision-makers in the Immigration and Refugee Board (IRB). This designation further reduced the time it takes to process a Mexican refugee claim to 45 days for those who file a refugee claim at a port of entry, and 30 days after referral for those who make a claim at an inland immigration office. Furthermore, Mexican refugee claimants became ineligible to apply for work permits.

Recent developments in Canada's legal system have limited access to such rights for many people in Mexico who face a very real threat of persecution, harassment, and violence. For reasons explained below, the expedited procedures created by Bill C-31 for example, allow for LGBT people with a well-founded fear of persecution to be sent back to their country of origin where they may face persecution, violence, or possibly death. Additionally, Canada's Immigration and Refugee legislation recently recognized guardianship and spousal bonds based on documentation in the claimants' country of origin. The effect of this is that Canada does not recognize the family bonds of LGBT claimants from countries, like Mexico, that discriminate against LGBT families. LGBT refugees from Mexico will face an expeditious process, with a 45-day processing time (rather than the previous 171 days) for those who make a refugee claim at a port of entry, and 30 days for those who file a claim at an inland office for Citizenship and Immigration. This is especially problematic for LGBT claimants. As noted by researchers at the Simon Fraser University, because of the requirement of documentary evidence for claims based on sexual orientation and gender identity, LGBT claimants often need more time to gather the relevant documents. ${ }^{92}$ Even LGBT asylum seekers with a very valid claim of persecution may not be able to compile documentary evidence of their sexual orientation or gender identity, or the persecution they face, in time for these procedures. After having their application expeditiously declined, LGBT refugees from countries labelled "safe" will no longer have the right to appeal the decision, or to make a claim under humanitarian and compassionate grounds. These requirements violate UN High Commissioner for Refugees guidelines on the treatment of SOGI refugees, which recognize that many LGBT people will not have lived openly as LGBT in their countries of origin. ${ }^{93}$ It notes that many claimants facing

92 Simon Fraser University, Gender-persecuted refugees need support, MEDIA RELEASE (November 22, 2012), available at http://wrerresfu.ca/pamr/media-releases/2012/gender-persecuted-refugees-needsupport.html (last visited July 28, 2018).

93 United Nations High Commissioner for Refugees, Guidelines on international protection no. 9: Claims to Refugee Status based on Sexual Orientation and/or Gender Identity within the context of Article 1A(2) of the 1951 Convention and/or its 1967 Protocol relating to the Status of Refugees (2012), available at http://werre.unhcrorg/publications/legal/50ae466f9/guidelines-international-protection-9-claims-refugeestatus-based-sexual.html (last visited July 27, 2018). 
real persecution struggle to produce the requested documents and it fosters procedures that are sensitive to their circumstances.

Additionally, LGBT claimants may have difficulty disclosing aspects of their sexual orientation or gender identity, or may express them in ways inconsistent with Canadian terminology for SOGI. For instance, a 2007 Federal Court ruling noted that the claimant was hesitant to acknowledge her gender identity to immigration officials for fear of persecution. ${ }^{94}$ Expedited procedures are inadequate for providing a fair hearing where a person must disclose information to immigration officials, because of the discrimination and potential violence they have experienced from public officials in their country of origin. Accommodations are currently available for vulnerable people seeking asylum, ${ }^{95}$ but the reduced trial period may also limit a person's ability to seek and obtain accommodations in time.

Canada's refugee and immigration programs allow refugee claimants and immigrants to list family members who were unable to accompany them when they entered Canada, but will join them at a later date. However, Canada's refugee and immigration system creates very specific barriers for LGBT families as it relies on the recognition of family bonds given by the family's country of origin. Canada allows refugees and immigrants to list their spouses as non-accompanying family members, but does not allow common-law partners to do so. As a result, Canada does not recognize partnerships where couples from countries that do not recognize same-sex marriage. A couple fleeing a country due to persecution based on sexual orientation usually does not have access to marriage equality in their country of origin, and is unlikely to have travelled to another country to get a marriage license. The result is that same-sex partners who travel to Canada separately are most often unable to take advantage of the one-year window that Canada offers to opposite-sex spouses.

Canada's refugee and immigration programs also allow claimants to list dependent children who were not able to travel with them. This can occur when families are separated due to the persecution that led to their refugee claim. However, Canada's system creates specific barriers for LGBT families who are forced to travel separately. Most governments worldwide do not allow individuals to adopt their same-sex partner's biological child, or allow same sex partners to jointly adopt. As a result, Canada does not recognize that many parents in same-sex relationships are parents to their own children, and are, in turn, not able to access the resources available to parents in opposite-sex relationships. LGBT people face a high risk of persecution, violence, and even death in Mexico. Canada's designated country of origin list

\footnotetext{
94 Hernandez v. Canada, [2007] F.C.J. No. 1665.

95 Immigration and Refugee Board of Canada, Chairperson Guideline 8: Procedures weith Respect to Vulnerable Persons Appearing Before the IRB (Effective Date: Dec. 15, 2006. Amended Dec.15, 2012), available at https://irb-cisr.gc.ca/en/legal-policy/policies/Pages/GuideDir08.aspx (last visited July 27, 2018).
} 
Esta revista forma parte del acervo de la Biblioteca Jurídica Virtual del Instituto de Investigaciones Jurídicas de la UNAM http://www.juridicas.unam.mx/ https://biblio.juridicas.unam.mx/bjv https://revistas.juridicas.unam.mx/ http://dx.doi.org/10.22201/iij.24485306e.2019.1.13128

has the effect of requiring refugee boards to use expedited procedures with this vulnerable group. LGBT claimants are forced to prove intimate aspects of their personal lives, facets that have been denied by their government and community, and face the threat of having no right to an appeal. Additionally, Canada's IRB is not currently prepared to acknowledge family bonds that are denied because of State persecution. After discussing the discrimination and human rights violation in Canada toward Mexican refugee and asylum seekers, the next section will focus on Canada's international obligation to protect claimants through the principle of non-refoulement. ${ }^{96}$

\section{Canada's International Obligations toward Refugee Protection}

Canada is obligated under the Convention Relating to the Status of Refugees (the Convention) and the International Covenant on Civil and Political Rights $^{97}$ (ICCPR) to provide asylum to those who have a well-founded belief of persecution. The words of Article 9 of the ICCPR, ${ }^{98}$ liberty and security of person form the basis for sec. 7 of the Charter of Rights and Freedoms of Canada. ${ }^{99}$ Canada is a signatory of the Refugee Convention and its 1967

96 Non-refoulement is a fundamental principle of international law which forbids a country receiving asylum seekers from returning them to a country in which they would be in likely danger of persecution based on «race, religion, nationality, membership of a particular social group or political opinion»; See also Seline Trevisault, The Principle of Non-Refoulement And the De-Territorialization of Border Control at Sea, 27 LeIDEn J. InT'L. L. 3 (2014).

97 Adopted and opened for signature, ratification and accession by General Assembly resolution 2200A (XXI) of 16 December 1966, entry into force 23 March 1976, in accordance with Article 49.

98 Article 9:

1. Everyone has the right to liberty and security of person. No one shall be subjected to arbitrary arrest or detention. No one shall be deprived of his liberty except on such grounds and in accordance with such procedure as are established by law.

2. Anyone who is arrested shall be informed, at the time of arrest, of the reasons for his arrest and shall be promptly informed of any charges against him.

3. Anyone arrested or detained on a criminal charge shall be brought promptly before a judge or other officer authorized by law to exercise judicial power and shall be entitled to trial within a reasonable time or to release. It shall not be the general rule that persons awaiting trial shall be detained in custody, but release may be subject to guarantees to appear for trial, at any other stage of the judicial proceedings, and, should occasion arise, for execution of the judgement.

4. Anyone who is deprived of his liberty by arrest or detention shall be entitled to take proceedings before a court, in order that that court may decide without delay on the lawfulness of his detention and order his release if the detention is not lawful.

5. Anyone who has been the victim of unlawful arrest or detention shall have an enforceable right to compensation.

99 Section 7 of the Canadian Charter of Rights and Freedoms is a constitutional provision that protects an individual ss autonomy and personal legal rights from actions of the government in Canada. There are three types of protection in this section: the right to life, liberty and secu- 
Protocol. ${ }^{100}$ Under the Refugee Convention, Canada has a duty to recognize any individual residing outside his or her country of nationality, who is unable or unwilling to return because of a "well-founded fear of persecution on account of race, religion, nationality, membership in a political social group, or political opinion" as a refugee. ${ }^{101}$ Once recognized, refugees are entitled to legal status and protection in Canada. A cornerstone of international refugee law and one of the most fundamental articles of the Refugee Convention is the principle of non-refoulement, ${ }^{102}$ which is the practice of not returning refugees to experience persecution or danger based on one of the five Convention reasons, mentioned ${ }^{103}$ In addition to an obligation to recognize refugees and the prohibition against non-refoulement as signatory to the Refugee Convention, Canada has a duty not to discriminate against refugee claimants for reasons of "race, religion or country of origin." 104 A Harvard Law School's Human Rights Program, Global Rights, International Gay and Lesbian Human Rights Commission, and Colectivo Binni Laanu A.C. report prepared for the UN Human Rights Committee has demonstrated how the persecution faced by many people in Mexico violate the ICCPR. ${ }^{105}$ Obligations to protect people facing persecution of this type are enshrined in Canada's refugee laws, which promise to provide asylum to those who fit the definition of a refugee under the Convention.

That sense of conflicting obligations has played out in Canada in cases where the IRB has been reluctant to extend asylum to wealthy Mexicans, and the federal court has ordered it to reconsider. In several cases, including Balcorta's, the IRB has concluded that moneyed Mexicans do not qualify for asylum because all Mexicans face gang-related crime, and the Immigration and Refugee Protection Act offers no protection against "a risk faced generally by other individuals." The court, however, has held that a wealthy

rity of the person. Denials of these rights are constitutional only if the denials do not breach what is referred to as fundamental justice. This Charter provision provides both substantive and procedural rights. It has broad application beyond merely protecting due process in administrative proceedings and in the adjudicative context, and has in certain circumstances touched upon major national policy issues such as entitlement to social assistance and public health care. As such, it has proven to be a controversial provision in the Charter.

100 Convention Relating to the Status of Refugees \& Protocol Relating to the Status of Refugees, supra note 45.

101 Refugee Convention, supra note 45, at art 1.

102 UN High Commissioner for Refugees (UNHCR), UNHCR Note on the Principle of NonRefoulement (November 1997), available at http://werere.refworld.org/docid/438c6d972.html (last visited July 28, 2018).

103 Refugee Convention, supra note 45, at art 33.

104 Id.at art 3

105 Letra S, Sida, Cultura y Vida Cotidiana, A.C., Human Rights Violations Against Lesbian, Gay, Bisexual, Transgender and Intersex (LGBTI) People in Mexico: A Shadow Report (July 2014), available at http://tbinternet.ohchrorg/Treaties/CCPR/Shared\%20Documents/MEX/ INT_CCPR_ICS_MEX_17477_E.pdf(last visited July 27, 2018). 
person singled out by the gangsters faces a very specific threat. "The risks of those standing in the same vicinity of the gunman," wrote Justice Michel Shore when sending Balcorta's case back for another IRB hearing, "cannot be considered the same as the risks of those standing directly in front of him." Such cases pose a dilemma for countries like Canada. Giving safe haven to Mexico's skilled and wealthy flies in the face of the spirit of NAFTA. There is no such thing as witness protection in Mexico, only five per cent of crimes are solved, and only two per cent result in a conviction revealing the basic collapse of judicial and law enforcement systems. In Canada, the IRB does not track claimants by income, and its decisions remain private unless an applicant appeals to federal court, but the handful of cases in the public domain point to a disturbing pattern. The stalemate is unlikely to last. Canada has lifted the visa requirement on Mexicans travelling to Canada - a move that could open the gates to another flood of asylum claims. To avoid that scenario, Canada added Mexico to Canada's list of "designated safe" countries, which make it easier to deport refugee claimants after the IRB rejects them. The federal court has "[examined] some of these IRB decisions, found that they got it wrong and sent them back." Under the current designation scheme, "safe" countries are supposed to recognize "basic democratic rights and freedoms" and provide "mechanisms for redress if those rights or freedoms are infringed," in order to be reviewed for possible designation. ${ }^{106}$

\section{Conclusion}

Canada-Mexico relations have not been extensively addressed by scholars, beyond Canada's TFWP, which targets Mexican laborers since its expansion in 1974. After the inclusion of Mexicans in the program, mainly in agricultural work, their numbers in Canada began to grow very quickly. The number of Mexicans in Canada has risen over the years due to several reasons, including the creation of the NAFTA in 1994. This agreement had a major role in the increase of Mexicans in Canada mainly due to an upsurge in temporary work to compensate for labor shortages, which aided Mexicans who at the time were suffering from an overwhelmingly high unemployment rate. Also, the high unemployment rate triggered the growth of illegal market activity and violence associated with drug-trafficking, causing Mexicans to fear for their lives due to threats and general violence in Mexico. As a result, in recent years migration from Mexico to Canada has multiplied at an exponential rate.

The most significant and notable increase has been in the number of refugee claims from Mexicans seeking asylum in Canada. It has been found that Canada is the number one destination for Mexican refugee claimants. Can-

106 Government of Canada, Designated countries of origin policy, supra note 68. 
ada accepts their claims at an alarmingly low rate compared to claims from other nations, even other nations in Latin America. This leaves Mexicans with very few options to turn to for protection from violence. Canada has now seen a drop in the overall number of Mexicans living in Canada due to its new restrictionist immigration attitude towards Mexicans. While Canada is still accepting and using large numbers of Mexicans for temporary work, other methods of immigration have been nearly completely shut off to Mexicans. This has left many Mexicans with nowhere else to turn in their time of need in view of the violence and danger caused by drug-trafficking, gangs, and corruption in Mexico. In the future, this very recent change in policies might hurt Mexico's economic relationship with Canada, especially with regards to the use of Mexicans for temporary labor. Such a potential pitfall will likely occur if the United States chooses to implement a large-scale temporary worker program as part of its upcoming immigration reform. Otherwise, the United States might see a slight increase in undocumented immigration from Mexico, as those who are turned away from Canada might choose to take their chances in the U.S. I contend that the reason Mexicans chose Canada to claim refugee status is Canada's long history of open immigration policy, especially in view of its economic and temporary labor agreements with Canada that have given Mexicans the impression that they are much welcomed in Canada. This proved false when Canada changed its immigration and refugee policies in 2009, 2010, and 2012, in response to the overwhelming number of Mexican refugee claims.

I also argue that most Mexican asylum claimants are not eligible for asylum in Canada because Canada designated Mexico a 'safe' nation" on February 15, 2013, despite the opposition of human rights experts. ${ }^{107}$ As a signatory of the 1951 Refugee Convention and its 1967 Protocols, Canada is bound by the principle of non-refoulement and has a duty to not discriminate against refugee claimants on the grounds of race, religion or country of origin. Respecting the principle of non-refoulement, Canada can in fact respect its international commitment, but this is not often the case. Therefore, I suggest that Canada provide legal protection to all vulnerable Mexican refugee claimants by:

1. Removing Mexico from the list of designated safe countries.

2. Exhorting Mexico to implement genuine human rights reforms. As an important ally and trading partner, Canada could urge Mexico to invest in greater HIV prevention, care, treatment, and support, as well as insist that Mexico put an end to impunity for crimes against LGBTI individuals, women and girls, drug users, sex workers, and people living with HIV.

107 Government of Canada, Claim Refugee Protection from Inside Canada, https://wrere.canada. ca/en/immigration-refugees-citizenship/services/refugees/claim-protection-inside-canada.html (last visited July 27, 2018). 
3. Urging Mexico to ensure full, prompt, effective, impartial and diligent investigation and prosecution of the homicides perpetrated against women, migrants, journalists, human rights defenders, children, inmates and detainees, drug users, and LGBTI people, to put an end to impunity.

4. Offering support to Mexico in the implementation of training for all police, prosecutors, border control officers and judicial authorities on HIV, gender identity, sexual orientation, gender-based violence, sex work, drug use and harm reduction. (Canada has significant experience and resources on some of these issues, but should also enhance training for its own police, prosecutors and other authorities on these issues, where absent or inadequate). 